Journal of Mathematics and Statistics 4(1): 32-36, 2008

ISSN 1549-3644

(C) 2008 Science Publications

\title{
On Sandwich Theorems of Analytic Functions Involving Noor Integral Operator
}

\author{
Rabha W. Ibrahim and Maslina Darus \\ School of Mathematical Sciences, Faculty of Science and Technology \\ Universiti Kebangsaan Malaysia, Bangi 43600 Selangor D. Ehsan, Malaysia
}

\begin{abstract}
In this research, we introduce sufficient conditions for subordination and superordination for subclass of analytic functions containing Noor integral operator.
\end{abstract}

Key words: Noor integral operator, subordination, superordination

\section{INTRODUCTION}

Let $\mathrm{H}$ be the class of functions analytic in $\mathrm{U}$ and $\mathrm{H}[\mathrm{a}, \mathrm{n}]$ be the subclass of $\mathrm{H}$ consisting of functions of the form:

$$
f(z)=a+a_{n} z^{n}+a_{n+1} z^{n+1}+\ldots
$$

Let $\mathrm{A}$ be the subclass of $\mathrm{H}$ consisting of functions of the form:

$$
\mathrm{f}(\mathrm{z})=\mathrm{z}+\mathrm{a}_{2} \mathrm{z}^{2}+\ldots
$$

Let $F$ and $G$ be analytic functions in the unit disk $U$. The function $F$ is subordinate to $G$, written $F \prec G$, if $G$ is univalent $F(0)=G(0)$ and $F(U) \subset G(U)$. In general, given two functions $F(z)$ and $G(z)$, which are analytic in $\mathrm{U}$, the function $\mathrm{F}(\mathrm{z})$ is said to be subordination to $\mathrm{G}(\mathrm{z})$ in $U$ if there exists a function $h(z)$, analytic in $U$ with $h(0)$ and $|h(z)|<1$ for all $z \in U$ such that $F(z)=G(h(z))$ for all $\mathrm{z} \in \mathrm{U}$.

Let $\varphi: C^{2} \rightarrow C$ and let $\mathrm{h}$ be univalent in $\mathrm{U}$. If $\mathrm{p}$ is analytic in $U$ and satisfies the differential subordination $\left.\varphi(\mathrm{p}(\mathrm{z})), \mathrm{zp}^{\prime}(\mathrm{z})\right) \prec \mathrm{h}(\mathrm{z})$.

Then $\mathrm{p}$ is called a solution of the differential subordination. The univalent function $\mathrm{q}$ is called a dominant of the solutions of the differential subordination, $\mathrm{p} \prec \mathrm{q}$. If $\mathrm{p}$ and $\varphi(\mathrm{p}(\mathrm{z}))$, $\left.\mathrm{zp}^{\prime}(\mathrm{z})\right)$ are univalent in $U$ and satisfy the differential superordination $\mathrm{h}(\mathrm{z}) \prec \varphi(\mathrm{p}(\mathrm{z}))$, zp'(z)) then $\mathrm{p}$ is called a solution of the differential superordination.

An analytic function $q$ is called subordinant of the solution of the differential superordination if $q \prec p$. Denote by $\mathrm{D}^{\alpha}: \mathrm{A} \rightarrow \mathrm{A}$ the operator defined by:

$$
D^{\alpha} f(z):=\frac{z}{(1-z)^{\alpha+1}} * f(z), \alpha>-1
$$

where, $\left(^{*}\right)$ refers to the Hadamard product or convolution. Then implies that:

$$
\mathrm{D}^{\mathrm{n}} \mathrm{f}(\mathrm{z})={\frac{\mathrm{z}\left(\mathrm{z}^{\mathrm{n}-1} \mathrm{f}(\mathrm{z})\right)}{\mathrm{n} !}}^{(\mathrm{n})}, \mathrm{n} \in \mathrm{N}_{0}=\mathrm{N} \cup\{0\}
$$

We note that $D^{0} f(z)=f(z)$ and $D^{\prime} f(z)=z f^{\prime}(z)$.

The operator $\mathrm{D}^{\mathrm{n}} \mathrm{f}$ is called Ruscheweyh derivative of $\mathrm{n}$ th order of $f$.

Noor $^{[1]}$ defined and studied an integral operator $\mathrm{I}_{\mathrm{n}}: \mathrm{A} \rightarrow \mathrm{A}$ analogous to $\mathrm{D}^{\mathrm{n}} \mathrm{f}$ as follows:

Let $\mathrm{f}_{\mathrm{n}}(\mathrm{z})=\frac{\mathrm{z}}{(1-\mathrm{z})^{\mathrm{n}+1}}, \mathrm{n} \in \mathrm{N}_{0}$ and let $\mathrm{f}_{\mathrm{n}}{ }^{(-1)}$ be defined such that:

$$
\mathrm{f}_{\mathrm{n}}(\mathrm{z}) * \mathrm{f}_{\mathrm{n}}^{(-1)}(\mathrm{z})=\frac{\mathrm{z}}{1-\mathrm{z}}
$$

Then:

$$
\mathrm{I}_{\mathrm{n}} \mathrm{f}(\mathrm{z})=\mathrm{f}_{\mathrm{n}}^{(-1)}(\mathrm{z}) * \mathrm{f}(\mathrm{z})=\left(\frac{\mathrm{z}}{(1-\mathrm{z})^{\mathrm{n}+1}}\right)^{-1} * \mathrm{f}(\mathrm{z})
$$

Note that $I_{0} f(z)=z f^{\prime}(z)$ and $I_{1} f(z)=f(z)$. The operator $I_{n} f(z)$ is called the Noor Integral of $n$-th order of f. Using (1), (2) and a well- known identity for $\mathrm{D}^{\mathrm{n}} \mathrm{f}$ we have:

$$
(n+1) I_{n} f(z)-n I_{n+1} f(z)=z\left(I_{n+1} f(z)\right)^{\prime}
$$

Using hypergeometric functions ${ }_{2} \mathrm{~F}_{1},(2)$ becomes:

$$
\mathrm{I}_{\mathrm{n}} \mathrm{f}(\mathrm{z})=\left[\mathrm{z} \quad{ }_{2} \mathrm{~F}_{1}(1,1 ; \mathrm{n}+1, \mathrm{z})\right] * \mathrm{f}(\mathrm{z})
$$

where, ${ }_{2} \mathrm{~F}_{1}(\mathrm{a}, \mathrm{b} ; \mathrm{c}, \mathrm{z})$ is defined by:

Corresponding Author: Maslina Darus, Faculty of Science and Technology, School of Mathematical Sciences, Universiti Kebangsaan Malaysia, Bangi 43600 Selangor D. Ehsan, Malaysia 


$$
\begin{aligned}
& { }_{2} \mathrm{~F}_{1}(\mathrm{a}, \mathrm{b} ; \mathrm{c}, \mathrm{z}) \\
& =1+\frac{\mathrm{ab}}{\mathrm{c}} \frac{\mathrm{z}}{1 !}+\frac{\mathrm{a}(\mathrm{a}+1) \mathrm{b}(\mathrm{b}+1)}{\mathrm{c}(\mathrm{c}+1)} \frac{\mathrm{z}^{2}}{2 !}+\ldots
\end{aligned}
$$

The following definitions can be found in ${ }^{[2]}$.

Definition 1: Let $f \in A$ Then $f \in S^{*}$ (the starlike subclass of $\mathrm{A}$ ) if and only if for $\mathrm{z} \in \mathrm{U}$ :

$$
\operatorname{Re}\left\{\frac{\mathrm{z}\left[\mathrm{I}_{\mathrm{n}} \mathrm{f}(\mathrm{z})\right]^{\prime}}{\mathrm{I}_{\mathrm{n}} \mathrm{f}(\mathrm{z})}\right\}>0, \mathrm{n} \in \mathrm{N}_{0}
$$

Definition 2: Let $f \in A$. Then $f \in N_{(n)} * n \in N_{0}$ if and only if $I_{n} f \in S^{*}$ (the starlike subclass of $A$ ) for $z \in U$.

Definition 3: Let $f \in A$. Then $M^{*}$ (n) for $N_{0}$ if and only if there exists $\mathrm{g} \in \mathrm{N}_{(\mathrm{n})}$ * such that, for $\mathrm{z} \in \mathrm{U}$ :

$$
\operatorname{Re}\left\{\frac{\mathrm{z}\left[\mathrm{I}_{\mathrm{n}} \mathrm{f}(\mathrm{z})\right]^{\prime}}{\mathrm{I}_{\mathrm{n}} \mathrm{g}(\mathrm{z})}\right\}>0 \text {. }
$$

In the present study, we apply a method based on the differential subordination in order to obtain subordination results involving Noor Integral operator for a normalized analytic function $\mathrm{f}$ :

and

$$
\mathrm{q}_{1}(\mathrm{z}) \prec \frac{\mathrm{z}\left[\mathrm{I}_{\mathrm{n}} \mathrm{f}(\mathrm{z})\right]^{\prime}}{\mathrm{I}_{\mathrm{n}} \mathrm{f}(\mathrm{z})} \prec \mathrm{q}_{2}(\mathrm{z})
$$

$$
\mathrm{q}_{1}(\mathrm{z}) \prec \frac{\mathrm{z}\left[\mathrm{I}_{\mathrm{n}} \mathrm{f}(\mathrm{z})\right]^{\prime}}{\left[\mathrm{I}_{\mathrm{n}} \mathrm{g}(\mathrm{z})\right]} \prec \mathrm{q}_{2}(\mathrm{z}) .
$$

In order to prove our subordination and superordination results, we need the following definition and lemmas in the sequel.

Definition 4: Miller and Mocanu ${ }^{[3]}$. Denote by Q the set of all functions $f(z)$ that are analytic and injective on $\left\{\bar{U}-\mathrm{E}(\mathrm{f})\right.$ where $\mathrm{E}(\mathrm{f}):=\left\{\xi \in \partial \mathrm{U}: \lim _{\mathrm{z} \rightarrow \xi} \mathrm{f}(\mathrm{z})=\infty\right\}$ and are such that:

$$
\mathrm{f}^{\prime}(\xi) \neq 0 \text { for } \xi \in \partial \mathrm{U}-\mathrm{E}(\mathrm{f}) .
$$

Lemma 1: Miller and Mocanu ${ }^{[4]}$. Let $\mathrm{q}(\mathrm{z})$ be univalent in the unit disk $U$ and let $\theta$ and $\phi$ be analytic in a domain D containing $\mathrm{q}(\mathrm{U})$ with $\phi(w) \neq 0$ when $\mathrm{w} \in \mathrm{q}(\mathrm{U})$.

Set:

$$
\mathrm{Q}(\mathrm{z}):=\mathrm{zq}(\mathrm{z}) \phi(\mathrm{q}(\mathrm{z})), \mathrm{h}(\mathrm{z}):=\theta(\mathrm{q}(\mathrm{z}))+\mathrm{Q}(\mathrm{z})
$$

Suppose that:

- $\mathrm{Q}(\mathrm{z})$ is starlike univalent in $\mathrm{U}$ and

- $\operatorname{Re}\left\{\frac{\mathrm{zh} `(\mathrm{z})}{\mathrm{Q}(\mathrm{z})}\right\}>0$ for $\mathrm{z} \in \mathrm{U}$.

If

$$
\begin{aligned}
\theta(\mathrm{p}(\mathrm{z}))+ & \mathrm{zp} \mathrm{p}^{\prime}(\mathrm{z}) \phi(\mathrm{p}(\mathrm{z})) \\
& \prec \theta(\mathrm{q}(\mathrm{z}))+\mathrm{zq}^{\prime}(\mathrm{z}) \phi(\mathrm{q}(\mathrm{z}))
\end{aligned}
$$

then $\mathrm{p}(\mathrm{z}) \prec \mathrm{q}(\mathrm{z})$ and $\mathrm{q}(\mathrm{z})$ is the best dominant.

Lemma 2: Shanmugam, et al. ${ }^{[5]}$. Let $\mathrm{q}(\mathrm{z})$ be convex univalent in the unit disk $U$ and $\Psi$ and $\gamma$ in $C$ with:

$$
\operatorname{Re}\left\{1+\frac{\mathrm{zq} "(\mathrm{z})}{\mathrm{q}^{\prime}(\mathrm{z})}+\frac{\psi}{\gamma}\right\}>0
$$

If $\mathrm{p}(\mathrm{z})$ is analytic in $\mathrm{U}$ and $\psi \mathrm{p}(\mathrm{z})+\gamma \mathrm{zp}(\mathrm{z}) \prec \psi \mathrm{q}(\mathrm{z})+\gamma \mathrm{zq}(\mathrm{z})$ then $\mathrm{p}(\mathrm{z}) \prec \mathrm{q}(\mathrm{z})$ and $\mathrm{q}$ is the best dominant.

Lemma 3: Bulboaca $^{[6]}$. Let $\mathrm{q}(\mathrm{z})$ be convex univalent in the unit disk $U$ and $\vartheta$ and $v$ be analytic in a domain $D$ containing $q(U)$. Suppose that:

- $\quad \mathrm{zq}^{\prime}(\mathrm{z}) \varphi(\mathrm{q}(\mathrm{z}))$ is starlike univalent in $\mathrm{U}$ and

- $\operatorname{Re}\left\{\frac{\vartheta^{\prime}(\mathrm{q}(\mathrm{z}))}{\varphi(\mathrm{q}(\mathrm{z}))}\right\}>0$ for $\mathrm{z} \in \mathrm{U}$.

If $\mathrm{p}(\mathrm{z}) \in \mathrm{H}[\mathrm{q}(0), 1] \cap \mathrm{Q}, \quad$ with $\quad \mathrm{p}(\mathrm{U}) \subseteq \mathrm{D} \quad$ and $\vartheta(\mathrm{q}(\mathrm{z}))+\mathrm{zp}^{\prime}(\mathrm{z}) \varphi(\mathrm{p}(\mathrm{z}))$ is univalent in $\mathrm{U}$ and

$$
\begin{aligned}
\vartheta(\mathrm{q}(\mathrm{z})) & +\mathrm{zq}(\mathrm{z}) \varphi(\mathrm{q}(\mathrm{z})) \\
& \prec \vartheta(\mathrm{p}(\mathrm{z}))+\mathrm{zp}^{\prime}(\mathrm{z}) \varphi(\mathrm{p}(\mathrm{z}))
\end{aligned}
$$

then $\mathrm{q}(\mathrm{z}) \prec \mathrm{p}(\mathrm{z})$ and $\mathrm{q}(\mathrm{z})$ is the best subordinant.

Lemma 4: Miller and Mocanu ${ }^{[3]}$. Let $\mathrm{q}(\mathrm{z})$ be convex univalent in the unit disk $\mathrm{U}$ and $\gamma \in C$.

Further, assume that $\operatorname{Re}\{\bar{\gamma}\}>0$. If $\mathrm{p}(\mathrm{z}) \in \mathrm{H}[\mathrm{q}(0), 1] \cap \mathrm{Q}$ with $\mathrm{p}(\mathrm{z})+\gamma \mathrm{zp}(\mathrm{z})$ is univalent in $\mathrm{U}$ then $\mathrm{q}(\mathrm{z})+\gamma z \mathrm{q}^{\prime}(\mathrm{z}) \prec \mathrm{p}(\mathrm{z})+\gamma \mathrm{zp} \mathrm{\prime}^{\prime}(\mathrm{z})$ implies $\mathrm{q}(\mathrm{z}) \prec \mathrm{p}(\mathrm{z})$ and $\mathrm{q}(\mathrm{z})$ is the best subordinant.

\section{SANDWICH RESULTS}

By making use of Lemmas 1 and 2, we prove the following subordination results. 
Theorem 1: Let $\mathrm{q}(\mathrm{z}) \neq 0$ be univalent in $\mathrm{U}$ such that $\frac{\mathrm{z} \mathrm{q}^{\prime}(\mathrm{z})}{\mathrm{q}(\mathrm{z})}$ is starlike univalent in $\mathrm{U}$ and:

$$
\begin{gathered}
\operatorname{Re}\left\{1+\frac{\alpha}{\gamma} \mathrm{q}(\mathrm{z})+\frac{\mathrm{zq} \mathrm{q}^{\prime \prime}(\mathrm{z})}{\mathrm{q}^{\prime}(\mathrm{z})}-\frac{\mathrm{zq}^{\prime}(\mathrm{z})}{\mathrm{q}(\mathrm{z})}\right\}>0 \\
\alpha, \gamma \in \mathrm{C}, \gamma \neq 0 .
\end{gathered}
$$

If $\mathrm{f} \in \mathrm{A}$ satisfies the subordination:

$$
\begin{aligned}
& \alpha \frac{\mathrm{z}\left[\mathrm{I}_{\mathrm{n}} \mathrm{f}(\mathrm{z})\right]^{\prime}}{\mathrm{I}_{\mathrm{n}} \mathrm{f}(\mathrm{z})}+\gamma\left[1+\frac{\mathrm{z}\left[\mathrm{I}_{\mathrm{n}} \mathrm{f}(\mathrm{z})\right]^{\prime \prime}}{\left[\mathrm{I}_{\mathrm{n}} \mathrm{f}(\mathrm{z})\right]^{\prime}}-\frac{\mathrm{z}\left[\mathrm{I}_{\mathrm{n}} \mathrm{f}(\mathrm{z})\right]^{\prime}}{\mathrm{I}_{\mathrm{n}} \mathrm{f}(\mathrm{z})}\right] \\
& \prec \alpha \mathrm{q}(\mathrm{z})+\frac{\gamma \mathrm{z} \mathrm{q}^{\prime}(\mathrm{z})}{\mathrm{q}(\mathrm{z})}
\end{aligned}
$$

then

$$
\frac{\mathrm{z}\left[\mathrm{I}_{\mathrm{n}} \mathrm{f}(\mathrm{z})\right]^{\prime}}{\mathrm{I}_{\mathrm{n}} \mathrm{f}(\mathrm{z})} \prec \mathrm{q}(\mathrm{z})
$$

$\mathrm{q}(\mathrm{z})$ is the best dominant.

Proof: Our aim is to apply Lemma 1. Setting $p(z):=\frac{z\left[I_{n} f(z)\right]^{\prime}}{I_{n} f(z)}$. By computation shows that:

$$
\frac{\mathrm{zp}^{\prime}(\mathrm{z})}{\mathrm{p}(\mathrm{z})}=1+\frac{\mathrm{z}\left[\mathrm{I}_{\mathrm{n}} \mathrm{f}(\mathrm{z})\right]^{\prime \prime}}{\left[\mathrm{I}_{\mathrm{n}} \mathrm{f}(\mathrm{z})\right]^{\prime}}-\frac{\mathrm{z}\left[\mathrm{I}_{\mathrm{n}} \mathrm{f}(\mathrm{z})\right]^{\prime}}{\mathrm{I}_{\mathrm{n}} \mathrm{f}(\mathrm{z})}
$$

which yields the following subordination:

$$
\begin{gathered}
\alpha \mathrm{p}(\mathrm{z})+\frac{\gamma \mathrm{z} \mathrm{p}^{\prime}(\mathrm{z})}{\mathrm{p}(\mathrm{z})} \prec \alpha \mathrm{q}(\mathrm{z})+\frac{\gamma \mathrm{z} \mathrm{q}^{\prime}(\mathrm{z})}{\mathrm{q}(\mathrm{z})} \\
\alpha, \gamma \in \mathrm{C} .
\end{gathered}
$$

By setting $\theta(\omega):=\alpha \omega$ and $\varphi(\omega):=\frac{\gamma}{\omega}, \gamma \neq 0$, it can be easily observed that $\theta(\omega)$ is analytic in $C$ and $\varphi(\omega)$ is analytic in $C /\{0\}$ and that $\varphi(\omega) \neq 0$ when $C /\{0\}$. Also, by letting $Q(z)=\mathrm{zq}^{\prime}(\mathrm{z}) \varphi(\mathrm{q}(\mathrm{z}))=\gamma \mathrm{z} \frac{\mathrm{q}^{\prime}(\mathrm{z})}{\mathrm{q}(\mathrm{z})}$ and $\mathrm{h}(\mathrm{z})=\theta(\mathrm{q}(\mathrm{z}))+\mathrm{Q}(\mathrm{z})=\alpha \mathrm{q}(\mathrm{z})+\gamma \mathrm{z} \frac{\mathrm{q}^{\prime}(\mathrm{z})}{\mathrm{q}(\mathrm{z})}$.

We find that $\mathrm{Q}(\mathrm{z})$ is starlike univalent in $\mathrm{U}$ and that:

$$
\begin{aligned}
\operatorname{Re} & \left\{\frac{\mathrm{z} \mathrm{h}^{\prime}(\mathrm{z})}{\mathrm{Q}(\mathrm{z})}\right\} \\
= & \left\{1+\frac{\alpha}{\gamma} \mathrm{q}(\mathrm{z})+\frac{\mathrm{zq} \mathrm{q}^{\prime \prime}(\mathrm{z})}{\mathrm{q}^{\prime}(\mathrm{z})}-\frac{\mathrm{zq} \mathrm{\prime}^{\prime}(\mathrm{z})}{\mathrm{q}(\mathrm{z})}\right\}>0 .
\end{aligned}
$$

Then the relation (6) follows by an application of Lemma 1.

Corollary 1: If $f \in A$ and assume that (5) holds then:

$$
1+\frac{z\left[I_{n} f(z)\right]^{\prime \prime}}{\left[I_{n} f(z)\right]^{\prime}} \prec \frac{1+A z}{1+B z}+\frac{(A-B) z}{(1+A z)(1+B z)}
$$

implies $\frac{\mathrm{z}\left[\mathrm{I}_{\mathrm{n}} \mathrm{f}(\mathrm{z})\right]^{\prime}}{\mathrm{I}_{\mathrm{n}} \mathrm{f}(\mathrm{z})} \prec \frac{1+\mathrm{Az}}{1+\mathrm{Bz}},-1 \leq \mathrm{B}<\mathrm{A} \leq 1$ and $\frac{1+\mathrm{Az}}{1+\mathrm{Bz}}$ is the best dominant.

Proof: By setting $\alpha=\gamma=1$ and $q(\mathrm{z}):=\frac{1+\mathrm{Az}}{1+\mathrm{Bz}}$ where $-1 \leq \mathrm{B}<\mathrm{A} \leq 1$.

Corollary 2: If $\mathrm{f} \in \mathrm{A}$ and assume that (5) holds then:

$$
1+\frac{\mathrm{z}\left[\mathrm{I}_{\mathrm{n}} \mathrm{f}(\mathrm{z})\right]^{\prime \prime}}{\left[\mathrm{I}_{\mathrm{n}} \mathrm{f}(\mathrm{z})\right]^{\prime}} \prec \frac{1+\mathrm{z}}{1-\mathrm{z}}+\frac{2 \mathrm{z}}{1-\mathrm{z}^{2}}
$$

implies $\frac{\mathrm{z}\left[\mathrm{I}_{\mathrm{n}} \mathrm{f}(\mathrm{z})\right]^{\prime}}{\mathrm{I}_{\mathrm{n}} \mathrm{f}(\mathrm{z})} \prec \frac{1+\mathrm{z}}{1-\mathrm{z}}$ and $\frac{1+\mathrm{z}}{1-\mathrm{z}}$ is the best dominant.

Proof: By setting $\alpha=\gamma=1$ and $\mathrm{q}(\mathrm{z}):=\frac{1+\mathrm{z}}{1-\mathrm{z}}$.

Corollary 3: If $f \in A$ and assume that (5) holds then:

$$
1+\frac{\mathrm{z}\left[\mathrm{I}_{\mathrm{n}} \mathrm{f}(\mathrm{z})\right]^{\prime \prime}}{\left[\mathrm{I}_{\mathrm{n}} \mathrm{f}(\mathrm{z})\right]^{\prime}} \prec \mathrm{e}^{\mathrm{Az}}+\mathrm{Az}
$$

implies $\frac{\mathrm{z}\left[\mathrm{I}_{\mathrm{n}} \mathrm{f}(\mathrm{z})\right]^{\prime}}{\mathrm{I}_{\mathrm{n}} \mathrm{f}(\mathrm{z})} \prec \mathrm{e}^{\mathrm{A} z}$ and $\mathrm{e}^{\mathrm{A} z}$ is the best dominant.

Proof: By setting $\alpha=\gamma=1$ and $\mathrm{q}(\mathrm{z}):=\mathrm{e}^{\mathrm{Az}},|\mathrm{A}|<\pi$.

Theorem 2: Let $\mathrm{q}(\mathrm{z})$ be convex univalent in the unit disk $U$ and $\gamma$ in $C$ satisfies $\operatorname{Re}\left\{1+\frac{\mathrm{zq}^{\prime \prime}(\mathrm{z})}{\mathrm{q}^{\prime}(\mathrm{z})}+\frac{1}{\gamma}\right\}>0, \gamma \in \mathrm{C}$.

If $\mathrm{f}$ in $\mathrm{M}_{(\mathrm{n})}{ }^{*}$ for $\mathrm{n} \in \mathrm{N}_{0}$ and exists $\mathrm{g} \in \mathrm{N}_{(\mathrm{n})}{ }^{*}$ such that $\frac{\mathrm{z}\left[\mathrm{I}_{\mathrm{n}} \mathrm{f}(\mathrm{z})\right]^{\prime}}{\mathrm{I}_{\mathrm{n}} \mathrm{g}(\mathrm{z})}$ is analytic in $\mathrm{U}$ and the subordination $\frac{\mathrm{z}\left[\mathrm{I}_{\mathrm{n}} \mathrm{f}(\mathrm{z})\right]^{\prime}}{\mathrm{I}_{\mathrm{n}} \mathrm{g}(\mathrm{z})}\left\{1+\left[1+\frac{\mathrm{z}\left(\mathrm{I}_{\mathrm{n}} \mathrm{f}(\mathrm{z})\right)^{\prime \prime}}{\left(\mathrm{I}_{\mathrm{n}}(\mathrm{z})\right)^{\prime}}-\frac{\mathrm{z}\left(\mathrm{I}_{\mathrm{n}} \mathrm{g}(\mathrm{z})\right)^{\prime}}{\mathrm{I}_{\mathrm{n}} \mathrm{g}(\mathrm{z})}\right]\right\}$

$\prec \mathrm{q}(\mathrm{z})+\gamma \mathrm{zq}^{\prime}(\mathrm{z}), \gamma \in \mathrm{C}$

holds then: 
J. Math. \& Stat., 4 (1): 32-36, 2008

$$
\frac{\mathrm{z}\left[\mathrm{I}_{\mathrm{n}} \mathrm{f}(\mathrm{z})\right]^{\prime}}{\mathrm{I}_{\mathrm{n}} \mathrm{g}(\mathrm{z})} \prec \mathrm{q}(\mathrm{z})
$$

and $\mathrm{q}(\mathrm{z})$ is the best dominant.

Proof: Our aim is to apply Lemma 2. Setting $p(z):=\frac{z\left[I_{n} f(z)\right]^{\prime}}{I_{n} g(z)}$. By computation shows that:

$$
z^{\prime}(\mathrm{z})=\frac{\mathrm{z}\left[\mathrm{I}_{\mathrm{n}} \mathrm{f}(\mathrm{z})\right]^{\prime}}{\mathrm{I}_{\mathrm{n}} \mathrm{g}(\mathrm{z})}\left[1+\frac{\mathrm{z}\left(\mathrm{I}_{\mathrm{n}} \mathrm{f}(\mathrm{z})\right)^{\prime \prime}}{\left(\mathrm{I}_{\mathrm{n}} \mathrm{f}(\mathrm{z})\right)^{\prime}}-\frac{\mathrm{z}\left(\mathrm{I}_{\mathrm{n}} \mathrm{g}(\mathrm{z})\right)^{\prime}}{\mathrm{I}_{\mathrm{n}} \mathrm{g}(\mathrm{z})}\right]
$$

which yields the following subordination $\mathrm{p}(\mathrm{z})+\gamma \mathrm{z} \mathrm{p}^{\prime}(\mathrm{z}) \prec \mathrm{q}(\mathrm{z})+\gamma \mathrm{zq} \mathrm{q}^{\prime}(\mathrm{z}), \quad \gamma \in \mathrm{C}$. Thus in view of Lemma 2, (7) holds.

Theorem 3: Let $\mathrm{q}(\mathrm{z}) \neq 0$ be convex univalent in the unit disk U. Suppose that:

$$
\operatorname{Re}\left\{\frac{\alpha}{\gamma} \mathrm{q}(\mathrm{z})\right\}>0, \alpha, \gamma \in \mathrm{C}, \gamma \neq 0 \text { for } \mathrm{z} \in \mathrm{U}
$$

and $\frac{\mathrm{zq}^{\prime}(\mathrm{z})}{\mathrm{q}(\mathrm{z})}$ is starlike univalent in $U$. If $\frac{\mathrm{z}\left[\mathrm{I}_{\mathrm{n}} \mathrm{f}(\mathrm{z})\right]^{\prime}}{\mathrm{I}_{\mathrm{n}} \mathrm{f}(\mathrm{z})} \in \mathrm{H}[\mathrm{q}(0), 1] \cap \mathrm{Q}$ where $\mathrm{f} \in \mathrm{A}$,

$\alpha\left\{\frac{z\left[I_{n} f(z)\right]^{\prime}}{I_{n} f(z)}\right\}+\gamma\left\{1+\frac{z\left[I_{n} f(z)\right]^{\prime \prime}}{\left[I_{n} f(z)\right]^{\prime}}-\frac{z\left[I_{n} f(z)\right]^{\prime}}{I_{n} f(z)}\right\}$ is univalent in

$\mathrm{U}$ and the subordination

$$
\begin{aligned}
& q(z)+\frac{\gamma z q^{\prime}(z)}{q(z)} \prec \alpha\left\{\frac{z\left[I_{n} f(z)\right]^{\prime}}{I_{n} f(z)}\right\} \\
& +\gamma\left\{1+\frac{z\left[I_{n} f(z)\right]^{\prime \prime}}{\left[I_{n} f(z)\right]^{\prime}}-\frac{z\left[I_{n} f(z)\right]^{\prime}}{I_{n} f(z)}\right\}
\end{aligned}
$$

holds, then:

$$
q(z) \prec \frac{z\left[I_{n} f(z)\right]^{\prime}}{I_{n} f(z)}
$$

and $\mathrm{q}$ is the best subordinant.

Proof: Our aim is to apply Lemma 3.

Setting $p(z):=\frac{z\left[I_{n} f(z)\right]^{\prime}}{I_{n} f(z)}$. By computation shows that:

$$
\frac{z p^{\prime}(z)}{p(z)}=1+\frac{z\left[I_{n} f(z)\right]^{\prime \prime}}{\left[I_{n} f(z)\right]^{\prime}}-\frac{z\left[I_{n} f(z)\right]^{\prime}}{I_{n} f(z)}
$$

which yields the following subordination $\alpha \mathrm{q}(\mathrm{z})+\frac{\gamma \mathrm{z} \mathrm{q}^{\prime}(\mathrm{z})}{\mathrm{q}(\mathrm{z})} \prec \alpha \mathrm{p}(\mathrm{z})+\frac{\gamma \mathrm{z} \mathrm{p}^{\prime}(\mathrm{z})}{\mathrm{p}(\mathrm{z})}$ for $\alpha, \gamma \in \mathrm{C}$.

By setting $\theta(\omega):=\alpha \omega$ and $\varphi(\omega):=\frac{\gamma}{\omega}, \gamma \neq 0$ it can be easily observed that $\theta(\omega)$ is analytic in $C$ and $\varphi(\omega)$ is analytic in $C \backslash\{0\}$ and that $\varphi(\omega) \neq 0$ when $\omega \in \mathrm{C} \backslash\{0\}$. Also, we obtain $\operatorname{Re}\left\{\frac{\theta^{\prime}(\mathrm{q}(\mathrm{z}))}{\varphi(\mathrm{q}(\mathrm{z}))}\right\}=\operatorname{Re}\left\{\frac{\alpha}{\gamma} \mathrm{q}(\mathrm{z})\right\}>0$.

Then (9) follows by an application of Lemma 3.

Theorem 4: Let $\mathrm{q}(\mathrm{z})$ be convex univalent in the unit disk $U$ and $\gamma \in \mathrm{C}$. Further, assume that $\operatorname{Re}\{\bar{\gamma}\}>0$. If $\frac{\mathrm{z}\left[\mathrm{I}_{\mathrm{n}} \mathrm{f}(\mathrm{z})\right]^{\prime}}{\mathrm{I}_{\mathrm{n}} \mathrm{g}(\mathrm{z})} \in \mathrm{H}[\mathrm{q}(0), 1] \cap \mathrm{Q}$, with $\frac{\mathrm{z}\left[\mathrm{I}_{\mathrm{n}} \mathrm{f}(\mathrm{z})\right]^{\prime}}{\mathrm{I}_{\mathrm{n}} \mathrm{g}(\mathrm{z})}\left\{1+\left[1+\frac{\mathrm{z}\left(\mathrm{I}_{\mathrm{n}} \mathrm{f}(\mathrm{z})\right)^{\prime \prime}}{\left(\mathrm{I}_{\mathrm{n}} \mathrm{f}(\mathrm{z})\right)^{\prime}}-\frac{\mathrm{z}\left[\mathrm{I}_{\mathrm{n}} \mathrm{g}(\mathrm{z})\right]^{\prime}}{\mathrm{I}_{\mathrm{n}} \mathrm{g}(\mathrm{z})}\right]\right\}$ is univalent in $\mathrm{U}$ then $\mathrm{q}(\mathrm{z})+\gamma \mathrm{zq} \mathbf{\prime}^{\prime}(\mathrm{z})$

$\left.\prec \frac{\mathrm{z}\left[\mathrm{I}_{\mathrm{n}} \mathrm{f}(\mathrm{z})\right]^{\prime}}{\mathrm{I}_{\mathrm{n}} \mathrm{g}(\mathrm{z})}\left\{1+\left[1+\frac{\mathrm{z}\left(\mathrm{I}_{\mathrm{n}} \mathrm{f}(\mathrm{z})\right)^{\prime \prime}}{\left(\mathrm{I}_{\mathrm{n}} \mathrm{f}(\mathrm{z})\right)^{\prime}}\right\}-\frac{\mathrm{z}\left(\mathrm{I}_{\mathrm{n}} \mathrm{g}(\mathrm{z})\right)^{\prime}}{\mathrm{I}_{\mathrm{n}} \mathrm{g}(\mathrm{z})}\right]\right\}$ implies:

$$
q(z) \prec \frac{z\left[I_{n} f(z)\right]^{\prime}}{I_{n} g(z)}
$$

and $\mathrm{q}(\mathrm{z})$ is the best subordinant.

Proof: Our aim is to apply Lemma 4. Setting $\mathrm{p}(\mathrm{z}):=\frac{\mathrm{z}\left[\mathrm{I}_{\mathrm{n}} \mathrm{f}(\mathrm{z})\right]^{\prime}}{\mathrm{I}_{\mathrm{n}} \mathrm{g}(\mathrm{z})}$. By computation shows that $z^{\prime}(z)=\frac{z\left[I_{n} f(z)\right]^{\prime}}{I_{n} g(z)}\left\{1+\frac{z\left(I_{n} f(z)\right)^{\prime \prime}}{\left(I_{n} f(z)\right)^{\prime}}-\frac{z\left(I_{n} g(z)\right)^{\prime}}{I_{n} g(z)}\right\} \quad$ which yields the following subordination $\mathrm{q}(\mathrm{z})+\gamma \mathrm{zq}^{\prime}(\mathrm{z}) \prec \mathrm{p}(\mathrm{z})+\gamma \mathrm{z} \mathrm{p}^{\prime}(\mathrm{z}), \quad \gamma \in \mathrm{C}$. Thus in view of Lemma 4, we obtain (10). By combining Theorems 1 and 3 and Theorems 2 and 4 to get the following Sandwich theorems.

Theorem 5: Let $\mathrm{q}_{1}(\mathrm{z}) \neq 0, \mathrm{q}_{2}(\mathrm{z}) \neq 0$ be convex univalent in the unit disk $U$ satisfy (8) and (5) respectively. Suppose that and $\frac{\mathrm{zq}_{\mathrm{i}}{ }^{\prime}(\mathrm{z})}{\mathrm{q}_{\mathrm{i}}(\mathrm{z})}, \mathrm{i}=1,2$ is starlike univalent in $\mathrm{U}$. 


$$
\text { If } \quad \begin{aligned}
& \frac{z\left[I_{\mathrm{n}} \mathrm{f}(\mathrm{z})\right]^{\prime}}{\mathrm{I}_{\mathrm{n}} \mathrm{f}(\mathrm{z})} \in \mathrm{H}[\mathrm{q}(0), 1] \cap \mathrm{Q} \text { where } \mathrm{f} \in \mathrm{A}, \\
& \alpha\left\{\frac{\mathrm{z}\left[\mathrm{I}_{\mathrm{n}} \mathrm{f}(\mathrm{z})\right]^{\prime}}{\mathrm{I}_{\mathrm{n}} \mathrm{f}(\mathrm{z})}\right\}+\gamma\left\{1+\frac{\mathrm{z}\left[\mathrm{I}_{\mathrm{n}} \mathrm{f}(\mathrm{z})\right]^{\prime \prime}}{\left[\mathrm{I}_{\mathrm{n}} \mathrm{f}(\mathrm{z})\right]^{\prime}}-\frac{\mathrm{z}\left[\mathrm{I}_{\mathrm{n}} \mathrm{f}(\mathrm{z})\right]^{\prime}}{\mathrm{I}_{\mathrm{n}} \mathrm{f}(\mathrm{z})}\right\}
\end{aligned}
$$

univalent in $\mathrm{U}$ and the subordination

$\mathrm{q}_{1}(\mathrm{z})+\frac{\gamma \mathrm{z} \mathrm{\textrm {q } _ { 1 }}{ }^{\prime}(\mathrm{z})}{\mathrm{q}_{1}(\mathrm{z})} \prec$

$\alpha\left\{\frac{z\left[I_{\mathrm{n}} \mathrm{f}(\mathrm{z})\right]^{\prime}}{\mathrm{I}_{\mathrm{n}} \mathrm{f}(\mathrm{z})}+\gamma\left[1+\frac{\mathrm{z}\left[\mathrm{I}_{\mathrm{n}} \mathrm{f}(\mathrm{z})\right]^{\prime \prime}}{\left[\mathrm{I}_{\mathrm{n}} \mathrm{f}(\mathrm{z})\right]^{\prime}}-\frac{\mathrm{z}\left[\mathrm{I}_{\mathrm{n}} \mathrm{f}(\mathrm{z})\right]^{\prime}}{\mathrm{I}_{\mathrm{n}} \mathrm{f}(\mathrm{z})}\right]\right\}$

$\prec \alpha \mathrm{q}_{2}(\mathrm{z})+\frac{\gamma \mathrm{z} \mathrm{q}_{2}{ }^{\prime}(\mathrm{z})}{\mathrm{q}_{2}(\mathrm{z})}$

holds, then:

$$
\mathrm{q}_{1}(\mathrm{z}) \prec \frac{\mathrm{z}\left[\mathrm{I}_{\mathrm{n}} \mathrm{f}(\mathrm{z})\right]^{\prime}}{\mathrm{I}_{\mathrm{n}} \mathrm{f}(\mathrm{z})} \prec \mathrm{q}_{2}(\mathrm{z})
$$

and $\mathrm{q}_{1}(\mathrm{z})$ is the best subordinant and $\mathrm{q}_{2}(\mathrm{z})$ is the best dominant.

Theorem 5 reduces to the following known result obtained by Ali et al..$^{[7]}$

Corollary 4: Let the assumption of Theorem 5 holds

with $\mathrm{q}_{1}(0)=\mathrm{q}_{2}(0)=1$. Then $\mathrm{q}_{1}(\mathrm{z}) \prec \frac{\mathrm{z}[\mathrm{f}(\mathrm{z})]^{\prime}}{\mathrm{f}(\mathrm{z})} \prec \mathrm{q}_{2}(\mathrm{z})$

and $\mathrm{q}_{1}(\mathrm{z})$ is the best subordinant and $\mathrm{q}_{2}(\mathrm{z})$ is the best dominant.

Proof: By setting $\alpha=\gamma=1$ and $n=1$.

Corollary 5: Let the assumption of Theorem 5 holds. Then $\mathrm{q}_{1}(\mathrm{z}) \prec 1+\frac{\mathrm{z}[\mathrm{f}(\mathrm{z})]^{\prime \prime}}{[\mathrm{f}(\mathrm{z})]^{\prime}} \prec \mathrm{q}_{2}(\mathrm{z})$ and $\mathrm{q}_{1}(\mathrm{z})$ is the best subordinant and $\mathrm{q}_{2}(\mathrm{z})$ is the best dominant.

Proof: By setting $\alpha=\gamma=1$ and $n=0$.

Theorem 6: Let $\mathrm{q}_{1}(\mathrm{z}), \mathrm{q}_{2}(\mathrm{z})$ be convex univalent in the unit disk $\mathrm{U}$ such that

$$
\operatorname{Re}\left\{1+\frac{\mathrm{zq}_{2}{ }^{\prime \prime}(\mathrm{z})}{\mathrm{q}_{2}{ }^{\prime}(\mathrm{z})}+\frac{1}{\gamma}\right\}>0, \gamma \in \mathrm{C}, \operatorname{Re}\{\bar{\gamma}\}>0 \text {. }
$$

If $\mathrm{f} \in \mathrm{M}_{(\mathrm{n})}{ }^{*}$ for $\mathrm{n} \in \mathrm{N}_{0}$ and exists $\mathrm{g} \in \mathrm{N}_{(\mathrm{n})}{ }^{*}$ such that

$$
\frac{\mathrm{z}\left[\mathrm{I}_{\mathrm{n}} \mathrm{f}(\mathrm{z})\right]^{\prime}}{\mathrm{I}_{\mathrm{n}} \mathrm{g}(\mathrm{z})} \in \mathrm{H}\left[\mathrm{q}_{1}(0), 1\right] \cap \mathrm{Q}, \quad \text { with }
$$

$$
\frac{\mathrm{z}\left[\mathrm{I}_{\mathrm{n}} \mathrm{f}(\mathrm{z})\right]^{\prime}}{\mathrm{I}_{\mathrm{n}} \mathrm{g}(\mathrm{z})}\left\{1+\left[1+\frac{\mathrm{z}\left(\mathrm{I}_{\mathrm{n}} \mathrm{f}(\mathrm{z})\right)^{\prime \prime}}{\left(\mathrm{I}_{\mathrm{n}} \mathrm{f}(\mathrm{z})\right)^{\prime}}-\frac{\mathrm{z}\left(\mathrm{I}_{\mathrm{n}} \mathrm{g}(\mathrm{z})\right)^{\prime}}{\mathrm{I}_{\mathrm{n}} \mathrm{g}(\mathrm{z})}\right]\right\}
$$

is univalent in $\mathrm{U}$, then

is

$$
\begin{aligned}
& \mathrm{q}_{1}(\mathrm{z})+\gamma \mathrm{zq}_{1}{ }^{\prime}(\mathrm{z}) \\
& \prec \frac{\mathrm{z}\left[\mathrm{I}_{\mathrm{n}} \mathrm{f}(\mathrm{z})\right]^{\prime}}{\mathrm{I}_{\mathrm{n}} \mathrm{g}(\mathrm{z})}\left\{1+\left[1+\frac{\mathrm{z}\left(\mathrm{I}_{\mathrm{n}} \mathrm{f}(\mathrm{z})\right)^{\prime \prime}}{\left(\mathrm{I}_{\mathrm{n}} \mathrm{f}(\mathrm{z})\right)^{\prime}}-\frac{\mathrm{z}\left(\mathrm{I}_{\mathrm{n}} \mathrm{g}(\mathrm{z})\right)^{\prime}}{\mathrm{I}_{\mathrm{n}} \mathrm{g}(\mathrm{z})}\right]\right\} \\
& \prec \mathrm{q}_{2}(\mathrm{z})+\gamma \mathrm{zq}_{2}{ }^{\prime}(\mathrm{z}) \\
& \text { implies: }
\end{aligned}
$$

$$
\mathrm{q}_{1}(\mathrm{z}) \prec \frac{\mathrm{z}\left[\mathrm{I}_{\mathrm{n}} \mathrm{f}(\mathrm{z})\right]^{\prime}}{\mathrm{I}_{\mathrm{n}} \mathrm{g}(\mathrm{z})} \prec \mathrm{q}_{2}(\mathrm{z})
$$

and $\mathrm{q}_{1}(\mathrm{z})$ is the best subordinant and $\mathrm{q}_{2}(\mathrm{z})$ is the best dominant.

\section{ACKNOWLEDGMENT}

The study here was supported by SAGA: STGL012-2006, Academy of Sciences, Malaysia.

\section{REFERENCES}

1. Noor, K.I., 1999. On new classes of integral operators. J. Nat. Geom., 16 (1-2): 71-80.

2. Noor, K.I. and M.A.. Noor, 1999. On integral operators. J. Math. Anal. Appl., 238 (2): 341-352.

3. Miller, S.S. and P.T. Mocanu, 2003. Subordinants of differential superordinations. Complex Variables, 48 (10): 815-826.

4. Miller, S.S and P.T. Mocanu, 2000. Differential Subordinantions: Theory and Applications. Pure and Applied Mathematics No. 225 Dekker, New York.

5. Shanmugam, T.N., V. Ravichandran and S. Sivasubramanian, 2006. Differential sandwich theorems for some subclasses of analytic functions. Aust. J. Math. Anal. Appl., 3(1): 1-11.

6. Bulboaca, T., 2002. Classes of first-order differential superordinations. Demonstr. Math., 35 (2): 287-292.

7. Ali, R.M., V.Ravichandran, M.K. Hussain and G. Subramanian, 2005. Differential sandwich theorems for certain analytic functions. Far East J. Math. Sci., 15 (1): 87-94. 